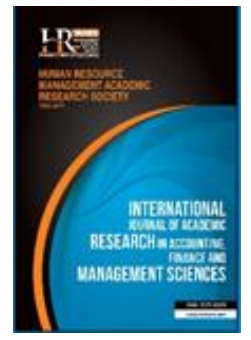

International Journal of Academic Research in Accounting, Finance and Management Sciences

Vol. 8, No.3, July 2018, pp. 103-117

E-ISSN: 2225-8329, P-ISSN: 2308-0337

(c) 2018 HRMARS

www.hrmars.com

To cite this article: Onyali, C.I., Okerekeoti, C.U. (2018). Board Heterogenity and Corporate Performance of Firms in Nigeria, International Journal of Academic Research in Accounting, Finance and Management Sciences 8 (3): 103117.

\title{
Board Heterogeneity and Corporate Performance of Firms in Nigeria
}

\author{
Chidiebele Innocent ONYALI ${ }^{1}$, Chinedu Uchenna OKEREKEOTI ${ }^{2}$ \\ ${ }^{1,2}$ Department of Accountancy, Faculty of Management Sciences, Nnamdi Azikiwe University, P.M.B. 5025, Awka, \\ Nigeria, E-mail: akadike two@yahoo.com
}

\begin{abstract}
The study ascertained the effect of board heterogeneity on performance of firms in Nigeria. Specifically, the study examined the effect of board size, women on board and board independence on return on assets of listed manufacturing firms on Nigerian Stock Exchange. The study adopted Ex-post facto research design. Population of the study is made up of seventy six manufacturing firms listed on the Nigerian Stock Exchange as at the year, 2016 while thirty two firms was used as sample of the study. The secondary data used in the study were sourced from the publications of Nigeria Stock Exchange and annual reports of the sampled firms. Multiple regression analysis with the aid of E-View 9.0 statistical software was used for data analysis. Findings of the study revealed that board size, women on board and board independence have significant and positive effect on return on assets of manufacturing firms listed on Nigerian Stock Exchange. Based on this, the study recommended among others that Firms should endeavor to diversify their board for improved groupthink and board effectiveness.

Key words Corporate governance, board heterogeneity, performance

Received: 30 Aug $2018 \quad$ (C) The Authors 2018

Revised: 21 Sept 2018 Published by Human Resource Management Academic Research Society (www.hrmars.com)

Accepted: 25 Sept 2018 This article is published under the Creative Commons Attribution (CC BY 4.0) license. Anyone may Published Online: 29 Sept 2018 reproduce, distribute, translate and create derivative works of this article (for both commercial and noncommercial purposes), subject to full attribution to the original publication and authors. The full terms of this license may be seen at: http://creativecommons.org/licences/by/4.0/legalcode
\end{abstract}

\section{Introduction}

Corporate governance is highly welcomed in business practices of today in order to close the gaps of business malfunctioning and irregularities noticed in the materiality of corporate issues. Effective corporate governance and regulation cannot exist in isolation from the world in which people (stakeholders) are ever demanding more accountability from firms. Good corporate governance is an essential key to a successful business operation and expansion, as it directs corporate actions or actions of managers to rethink management from the prism of both internal and external pressures for accountability and transparency (Visser, 2013; Nwagbara, 2014).

Corporate governance is the mechanism, process and practice by which companies are governed and controlled. Good corporate governance is a corporate set-up that leads to maximization of shareholders wealth legally, ethically and on a sustainable basis while ensuring equity and transparency to all stakeholders (Murthy, 2006). According to Nwanji and Howell (2004), the aim of corporate governance is to ensure that the boards of directors do their jobs properly. It also protects shareholders' right, enhances disclosure and transparency, facilitates effective functioning of the board and provides an effective legal and regulatory enforcement framework. It addresses the agency problem through a mix of the company law, stock exchange listing rules and self-regulatory Codes. Hence, corporate governance is the procedure by which shareholders pursue and ensure that their companies are run according to their objectives for accountability. It comprises processes of goal definition, monitoring, management, control and sanctioning. 
In a strict sense, it includes shareholders and management of a corporation as key actors; in a broader sense, it contains all actors (stakeholders) who contribute to the achievement of stakeholders' goals inside and outside the company.

The multiple cases of institutional failure across the globe in recent times have brought the attention of stakeholders to the makeup of corporate governance. The consequences of ineffective governance systems have severally led to corporate failure which not only affects the shareholders but also, the employees, suppliers, consumers and nations as a whole. Wahid, (2012) highlighted the unfortunate consequence that resulted from the corporate scandals that stormed the United States which led to the collapse of Enron, WorldCom, Dot-Com Bubble, Tyco and Xerox together with the subsequent liquidation of $\mathrm{HIH}$ insurance in Australia in the year 2001and Parmalatin Italy which is known as the biggest bankruptcy in Europe with estimated loss totalling \$20 billion and Oceanic Bank in Nigeria in 2009 among others.

It is against this backdrop that the Nigerian corporate world has taken steps to align their corporate governance mechanism with international best practice by following IFRSs framework to strengthen stakeholder confidence (Gonzalez et al., 2014). The collapse of these multinational companies which in most cases is traceable to failed external audit expectations has raised concern over the role played by the structure of the Board of Directors of the companies and this has brought about changes in corporate governance mechanisms one of which is board heterogeneity (Olaoti, 2016). Many practitioners have clamoured for this board heterogeneity with the argument that it can mitigate the effect of homogeneous board such as group think which is a phenomenon in which members' effort to achieve consensus override their ability to realistically appraise alternative courses of actions (Rhode and Packel, 2010). To this end, the United States Security and Exchange Commission in 2009 approved rules that require enhanced proxy statement disclosure regarding corporate governance and compensation matters. This rule requires public companies to disclose how they view diversity with respect to their boards. The concept of board heterogeneity implies diversity and there are various dimensions along which it can be looked at in the case of board structure. Schwizer et al., (2012) identified diversity or heterogeneity in board composition in terms of ethnicity, age, education, nationality and gender. While some of these differences are observable, others are not.

Among the arguments for this requirement is the fact that human resources in terms of women directors were untapped and minorities remain woefully represented. This argument that women directors and minorities were woefully represented was made possible with Alliance for Diversity Compiled Statistics of 2008 which shows that out of the composition of board members of fortune 100 companies; $71.5 \%$ were white men and only $28.5 \%$ of the board seats were occupied by women and minorities. Heterogeneity and homogeneity can be seen as two sides of a coin, where heterogeneity is best suited for handling ill-defined and novel problems while homogeneity is preferred for routine problems. Board heterogeneity can be manifested in diversity in skills, education, age, culture, gender, ethnicity and race among others.

While the boards are the main tool of internal governance mechanism, their efficacy may vary depending on their diversities (Olaoti, 2016). For instance, Enron's board as pointed out by Masulis et al. (2010) included two foreign independent directors in its audit committee. This aspect of diversity raises questions about the effectiveness of foreign directors' monitoring of a firm's operations and financial reporting. Agullar (2010) on the other hand favours board diversity in terms of having women directors in the board stating that companies that have heterogeneous boards perform better than boards without same.

Since Board is the "heart" of corporate governance where the outcome of a firm is often determined (Guerra et al., 2009; Yawson, 2006; Donaldson, 2003; Clarke, 2007; Fama and Bello, 2012), this study will focus on examining the effect of board size, women on board and board independence on corporate performance.

\subsection{Objective of the study}

The broad objective of this study is to ascertain the effect of board heterogeneity on performance of manufacturing firms in Nigeria. Specifically, the study will ascertain the effect of Board size, women on board and board independence on return on assets. 


\section{Literature review}

\subsection{Conceptual Framework}

\subsubsection{Corporate Governance}

Corporate governance is a concept that emerged following the growth of corporations in the 20th century, and in particular, following the stock market crash in 1929, which led scholars to argue for corporate governance mechanisms that would allow shareholders to keep companies in check (Wendel, 2014). A lot of scholars however attribute the considerable interest in corporate governance practices in modern corporations to the high profile collapse of a number of large firms in the US such as the Enron Corporation (Adodepe, 2014).

Aguilera, Filatotchev et al. (2007) define corporate governance as "mechanisms to ensure that executives respect the rights and interests of stakeholders, as well as hold them accountable for their actions with regard to the protection, generation and distribution of wealth." Kim and Nofsinger (2004) state that corporate governance originate as a result of corporate ownership and control being divided between two parties, namely stakeholders and management. A report by (World Bank, 2006) defines corporate governance as the structures and processes for the direction and control of companies; in order words, corporate governance concerns the relationship amongst the management, board of directors, controlling shareholders, minority shareholders and other stakeholders. Dombin (2013) defined corporate governance as the acceptance by management of the alienable rights of shareholders as the true owners of the corporation and their role as the trustees on behalf of the shareholders and other stakeholders.

Dar, Naseem et al. (2011) opines that corporate governance serves two major indispensable purposes which are (i) to enhance the performance of corporations by establishing and maintaining a corporate culture that motivates directors, managers and entrepreneurs to maximize the company's operational efficiency thereby ensuring returns on investment and long-term productivity. (ii) it ensures the conformance of corporations to laws, rules and practices which provide a mechanism to monitor directors' and managers' behaviour through corporate accountability that in turn safeguards the investor interest. Corporate governance comprises all measures such as optimal incentive or control structures which assure that investors get an adequate return for their investments (Von Arx and Ziegler, 2008). It is about the mechanisms that allow the principals (Shareholders) to reward and exert control on the agents (Servaes and Tamayo, 2013).

In a broader view, corporate governance is defined as the mechanisms of how shareholders delegate their power and authority to the board and corporate managers and how corporate managers allocate the firms' finite resources (financials, materials and human) to achieve the goal of maximizing profit, to the extent allowable by governing laws and company mandates. It encompasses the controls and procedures that exist to ensure that management acts in the interest of shareholders and stakeholders (Kanagaretnam et al., 2007).

Various researchers (see for example Filatotchev and Boyd 2009; Hambrick et al., 2008; Shipilov et al., 2010) attempted to investigate various aspects of corporate governance. Brajesh (2010) argues that corporate governance practices include a set of structural arrangements that align the management of organizations with the interests of stakeholders. Ireland, Hoskisson and Hitt (2009) assume that the separation and specialization of ownership (risk bearing) and managerial control (decision making) should lead to the highest return for its owners. However, often there is conflict between the objectives of the organization and those who act as custodians of the organization's assets and undertakings, namely the directors and senior executives. This is known as the principal agent problem or agency problem. Shareholders are the principals and the managers are the agents (Seal 2006). Hough, Thompson, Strickland and Gamble (2011) agree that this separation of ownership and control often leads to a conflict of interests. However, the duty of loyalty to the organization and its stakeholders requires undivided and unselfish loyalty and there should be no conflict between duty and self-interest. If managers follow an exclusive approach to governance they do not always act in the best interest of stakeholders (Kanda and Milhaupt 2003). Corporate governance practices, policies and procedures should thus ensure that it covers: Trusteeship, Transparency, Empowerment and accountability, Control and Ethical citizenship, the five critical areas which in essence capture the real nature of corporate governance (Fernando 2006). Various 
researchers (see for example Filatotchev and Boyd 2009; Hambrick et al., 2008; Shipilov et al., 2010) attempted to investigate various aspects of corporate governance. Brajesh (2010) argues that corporate governance practices include a set of structural arrangements that align the management of organizations with the interests of stakeholders. Ireland, Hoskisson and Hitt (2009) assume that the separation and specialization of ownership (risk bearing) and managerial control (decision making) should lead to the highest return for its owners. However, often there is conflict between the objectives of the organization and those who act as custodians of the organization's assets and undertakings, namely the directors and senior executives. This is known as the principal agent problem or agency problem. Shareholders are the principals and the managers are the agents (Seal 2006). Hough, Thompson, Strickland and Gamble (2011) agree that this separation of ownership and control often leads to a conflict of interests. However, the duty of loyalty to the organization and its stakeholders requires undivided and unselfish loyalty and there should be no conflict between duty and self-interest. If managers follow an exclusive approach to governance they do not always act in the best interest of stakeholders (Kanda and Milhaupt 2003). Corporate governance practices, policies and procedures should thus ensure that it covers: Trusteeship, Transparency, Empowerment \& accountability, Control and Ethical citizenship, the five critical areas which in essence capture the real nature of corporate governance (Fernando 2006).

\subsubsection{Board Size}

Board size represents the total head counts of directors seating on the corporate board. Size of the board is recognized as one of the unique features of Board dynamics with considerable but strategic impact on the board independence as well as the overall quality of corporate governance (Jensen 1993; Donaldson and Muth 1998; Shivdasani and Zenner, 2002). The size of board is vital to achieving the board effectiveness and improved firm performance especially from resource dependency perspective which place more emphasis on the board ability to co-opt limited and scares resource from various external links (Kiel and Nicholson, 2003). Board size affects the quality of deliberation among members and ability of board to arrive at optimal corporate decisions. However, determining an ideal size of the board has being an ongoing and controversial debate in corporate governance literature. Lipton and Lorch (1992) cited in Bello (2012) one of the early pioneers of board size proxy recommended a minimum of seven and maximum of nine board memberships. While, Jensen (1993) cited in Bello (2012) recommended an optimal size of eight, Shaw (1981) cited in Bello (2012) suggested board size of five which was supported by some subsequent empirical findings (e.g. Mak and Yuanto, 2003). Identifying the appropriate board size is of high significance because size can be detrimental to board effectiveness beyond certain limit (John and Senbet, 1998; Yermack, 1996 cited in Bello, 2012).

In relation to a relationship between the size of a board and a firm's improved performance, there are two distinct schools of thoughts. The first school of thought argues that a smaller board size will contribute more to the success of a firm (Lipton and Lorsch, 1992; Jensen, 1993; Yermack, 1996; cited in Vo and Phan, 2013). However, the second school of thought considers that a large board size will improve a firm's performance (Pfeffer, 1972; Klein, 1998; Coles and ctg 2008; cited in Vo and Phan, 2013). These studies indicate that a large board will support and advise firm management more effectively because of a complex of business environment and an organizational culture (Klein, 1998; cited in Vo and Phan, 2013).

The size of corporate board may affect the manner in which corporate directors conduct their responsibilities (Fama and Jensen, 1983; cited in Bello and Kamarul, 2017). This implies that the number of directors on corporate board may influence the ability of the board to monitor and assess management practices and procedures. Accordingly, several arguments arise in the literature on whether the size of corporate boards determines improved corporate performance. This argument always prevails due to the strategic posture of board members in companies' policies and strategies.

Among others, Akhtaruddin et al. (2009), Chang et al. (2012), Esa and Mohd-Ghazali (2012) provide evidence of a positive relationship between board size and improved corporate performance. Based on the positive findings, Esa and Mohd-Ghazali (2012) argued that larger boards offer more knowledge and experience and also put forward different ideas in board deliberations. Similarly, Haji and Mohd-Ghazali (2013) concluded that large board size is connected with increased monitoring capacity which could lead to sharing of a variety of experiences in boardrooms. Besides, a corporate governance-sustainability disclosure 
study conducted on a sample of 50 Pakistan companies by Lone, Ali, and Khan (2016) established that a large number of directors on corporate boards bring the experiences of diverse backgrounds which affect the level of corporate performance. More recently, Sadou et al. (2017) highlighted that larger boards are more effective and have greater influence over companies' performances.

On the other side, some literature provided evidence of a negative association between board size and sustainability disclosure. Accordingly, Said et al. (2009) evidenced a significant negative relationship between board size and corporate performance, advocating that large board size result to ineffectiveness in communication coordination and decision-making. However, a study conducted on a sample of public listed Indonesian companies by Siregar and Bachtiar (2010) found a non-linear relationship between board size and improved corporate performance. The study noted that a large board would be able to exercise better monitoring, but too large board will render the monitoring process ineffective.

In Nigeria, the rule guiding the size of a corporate board is spelled out in the country's corporate governance code. Specifically, the revised code of corporate governance 2011 stipulates that corporate board size should be relative to the complexity and scale of companies' operations. The code further specifies that the number of directors in company's board should not fall below five (5). However, the governance code did not specify the maximum number of directors a company should appoint for any specified period. Therefore, considering the provision in Nigeria's revised corporate governance code and in relation to the provision of stakeholder theory which supports larger size board, this study expects board size to have a positive effect on corporate performance.

\subsubsection{Independent Board of Directors}

Independent directors are directors that have no personal or professional relationship with a company, other than being a board member. They are also often referred to as external directors. The presence of independent directors on a board can help to segregate the management and control tasks of a company and this is expected to offset inside members' opportunistic behaviours (Jensen and Meckling, 1976 cited in Hussain et al., 2016). In addition, independent directors generally have stronger and extended engagement with wider groups of stakeholders (Wang and Dewhirst, 1992 cited in Hussain et al., 2016) and they tend to have a broader perspective that is likely to result in a greater exposure to performance requirements (Rupley et al., 2012).

Directors on corporate boards have different values, interest and time horizons (Post et al., 2011). However, despite several support for independent directors on corporate boards, debates were still ongoing whether independent directors are able mechanism for aligning managerial interests with those of shareholders and also their value creation merits for improved corporate performance.

A study conducted on a sampled US firms by Zhang, Zhu, and Ding (2013) claims that independent directors have more diverse background and represents external stakeholders of companies. As such, they have a stronger orientation towards better operation strategies than their counterparts in the boardroom. Studies by Huang (2010), Khan (2010), Jo and Harjoto (2012), Sharif and Rashid (2014), Kaur et al., (2016) indicated a positive link between board independence and improved corporate performance. Based on a positive result, Huang (2010) concluded that independent directors act as a monitoring mechanism that ensures companies are properly managed by corporate management and also work towards enhancing corporate image and performance.

Conversely, Michelon and Parbonetti (2012), Janggu et al. (2014) provided evidence of an insignificant relationship between independent directors and improved corporate performance. This suggests that board independence does not seem to play a vital role in improving or determining a firm's extent of performance. Based on the insignificant result observed, Abdullah et al. (2011) affirmed that independent directors are not effective in discharging their duties; talk less of going against other members of the boards. Additionally, Al-Moataz and Hussainey (2012) reiterated that higher number of independent directors on companies' boards leads to less effective board monitoring and equally lower levels of corporate transparency.

From the perspective of stakeholder theory, managers are perceived as moral agents other than opportunistic individual. As such, their role is to achieve a balance between the interests of diverse stakeholders (Shankman, 1999; cited in Bello and Kamarul, 2017). Therefore, it is presumed that a 
corporate board with a higher proportion of independent directors will ensure improved board monitoring quality and also work toward satisfying the needs of all stakeholders. Therefore, based on stakeholder theory's declaration and the positive result observed in the extant literature, this study anticipates a significant positive relationship between board independence and improved corporate performance. This implies that with a higher proportion of independent directors on a corporate board, a company will exhibit more concern and give more attention to improved corporate performance.

\subsubsection{Women on Board}

Women on board reflect a diversified characteristic of the board (Dutta và Bose, 2006). Adams and Ferreira (2009) raised the issue of the importance of women on a board in their proposals for governance reform. Rao et al. (2012) have also stated that the recognition of women directors' contribution has continuously risen. Some of the benefits of having women on the board have been highlighted in prior studies:

a. More committed and involved; more prepared; more diligent; and creates better atmosphere (Huse and Solberg, 2006)

b. Improves decision making process; increases board effectiveness; and better attendance and participation (Adams and Ferreira, 2009)

c. Demonstrates greater responsibilities; more philanthropically driven; less concerned with economic performance (Ibrahim and Angelidis, 2011)

d. Enhances board independence (Kang et al., 2007)

e. Associated with firms that are more socially responsible (Webb, 2004)

f. Increases board effectiveness and shareholder value (Carter et al., 2003).

A growing body of contemporary research on boards and board roles suggested that diversity in the Boardroom has the potential to increase board effectiveness and firm performance (Carter et al., 2003). Board diversity in this context refers to the presence of women directors on corporate boards. Board diversity facilitates in-depth discussions and alternative perspectives and is more likely to be beneficial in the course of uncertainties and complex decisions. A board with female members is more able to integrate the interest of multiple stakeholders, including employees, customers, suppliers and the communities with the performance-based interests of shareholders (Harrison and Coombs, 2012). Recruitment of more women into corporate boards is likely to bring about diversity of opinions and perspective to board discussion including deliberations on sustainability disclosure issues. Therefore, a board with greater diversity is likely to increase companies' ability to recognize the need and interest of various stakeholder groups identify best strategies that will align the varied interests and to manage potential conflict between shareholders (Harjoto et al., 2014).

Smith et al. (2006) cited in Vo and Phan, (2013) considered three different reasons to recognize the importance of females on a board. First, female board members usually have a better understanding of a market in comparison with male members. As such, this understanding will enhance the decisions made by the board. Second, female board members will bring better images in the perception of the community for a firm and this will contribute positively to firm's performance. Third, other board members will have enhanced understanding of the business environment when female board members are appointed. Hence, as a result of women on board, a firm's performance is improved directly and indirectly.

A growing body of contemporary research on boards and board roles suggested that women directors on board have the potential to increase board effectiveness and firm performance (Carter et al., 2003; cited in Bello and Kamarul, 2017). Women on board facilitate in-depth discussions and alternative perspectives and are more likely to be beneficial in the course of uncertainties and complex decisions. A board with female members is more able to integrate the interest of multiple stakeholders, including employees, customers, suppliers and the communities with the performance-based interests of shareholders (Harrison and Coombs, 2012). Recruitment of more women into corporate boards is likely to bring about diversity of opinions and perspective to board discussion including deliberations on performance issues. Therefore, a board with greater diversity is likely to increase companies' ability to recognize the need and interest of various stakeholder groups identify best strategies that will align the varied interests and to manage potential conflict between shareholders (Harjoto et al., 2014). 
Based on the different perceptions in prior literature, several studies attempted to examine the effect of women on board on companies' performance. Setó-Pamies (2013) argued in favor of board diversity that, the presence of women in corporate boardrooms improves the relationship with stakeholders, increase accountability, shows greater concern for the environment and prompts more ethical behavior. More recently, Rao and Tilt (2015) conducted a comprehensive review of prior board diversity and overall corporate performance. Based on the review, Rao and Tilt concluded that the impact of having females on corporate board is likely to be minimal except when there is a critical mass. However, from the viewpoint of stakeholder theory, the presence of females in corporate boardroom is a signal to companies' stakeholders that, such company is socially responsible and also pays more attention to the needs of diverse stakeholders (Bear et al., 2010).

In the context of Nigeria, culture plays a pivotal role in restricting women's participation in corporate boards. However, this perception is gradually fading out. As such the significance of gender diversity is nowadays becoming obvious and visible (Şener and Karaye, 2014). An example is the recent measure put in place by the Central Bank of Nigeria (CBN) to boost female representation in board formation in the country. The CBN through its banker's committee imposes mandatory quota target on deposit money banks. The aim is to increase women's representation on companies' boards to 30 percent (Şener and Karaye, 2014). Therefore, considering the recent changes in Nigerian gender diversity policies and also the view of stakeholder theory which supports a positive association between board diversity and firm performance, this study expects women on board to have a positive and significant effect on firm performance.

\subsubsection{Corporate Performance}

The outcome of management processes, from strategic planning to implementation of the plan, underpins the measurement of corporate performance. Thus, corporate performance refers to the end result of management processes in relation to corporate goals. Daft (1991) cited in Fauzi et al. (2010) defined corporate performance as the organization's ability to attain its goals by using resources in an efficient and effective manner. There are different perspectives on the measurement of corporate performance in strategic management literature (Fauzi et al., 2010). For example, Ventrakaman and Ramanujam (1986) cited in Fauzi et al. (2010) divide corporate performance into operational and financial performances. Operational performance includes: (i) market share, (ii) product quality, and (iii) marketing effectiveness. Financial performance is broken down into two subcategories: (i) market-based performance (e.g., stock price, dividend payout and earnings per share) and (ii) accounting-based performance (e.g., return on assets and return on equity). The concept of corporate performance in accounting literatures refers normally to financial aspects such as profit, return on assets (ROA) and economic value added (EVA) among others. For this study, corporate performance will be measured with Return on asset.

\subsubsection{Return on Asset}

Return on Assets (ROA) represents the amount of earnings (before interest and tax) a company can achieve for each naira of assets it controls and is a good indicator of a firm's profitability. According to Hagel, Brown and Davison (2010) ROA explicitly takes into account the assets used to support business activities. It determines whether the company is able to generate an adequate return on these assets rather than simply showing robust return on sales. Asset-heavy companies need a higher level of net income to support the business relative to asset light companies where even thin margins can generate a very healthy return on assets. Using ROA as a key performance metric quickly focuses management attention on the assets required to run the business.

\subsection{Theoretical Framework}

This study is anchored on Stakeholder and Agency theory.

\subsubsection{Stakeholder Theory (Freeman, 1984)}

The traditional definition of a stakeholder is 'any group or individual who can affect or is affected by the achievement of the organization's objectives' (Freeman 1984 in Fontaine et al., 2006; Aoadokaa, 2015). 
The general idea of the stakeholder concept is a redefinition of the organization. In general the concept is about what the organization should be and how it should be conceptualized. Fontaine et al. (2006) states that the organization itself should be thought of as grouping of stakeholders and the purpose of the organization should be to manage their interests, needs and viewpoints. This stakeholder management is thought to be fulfilled by the managers of a firm. The managers should on the one hand manage the corporation for the benefit of its stakeholders in order to ensure their rights and the participation in decision making and on the other hand the management must act as the stockholder's agent to ensure the survival of the firm to safeguard the long term stakes of each group.

\subsubsection{Agency Theory (Jensen and Meckling, 1976)}

Agency theory explains the conflicting relationship between managers and stakeholders assuming the presence of information asymmetry, opportunistic behaviour of agents, and conflicts of interests between principal (shareholder) and agent (manager).

Agency theory contends that effective corporate governance improves firm's capability to deal with emerging challenges and reduce the agency conflicts (Haniffa and Cooke 2005). Additionally, it maintains that the internal governance mechanisms must act effectively to hold the agents accountable for their actions (Li et al., 2008). The agency literature in this vein suggests that effective corporate governance enhances a firm's legitimacy (Michelon and Parbonetti 2012) and improves financial performance (Jo and Harjoto 2011). Keeping in view the stakeholders' demand for sustainable corporate development, Gul and Leung (2004) argue that the agency theory better explains the role of governance in stakeholders' management. Similarly, Haniffa and Cooke (2002) maintain that effective board performance is important in order to curb managers' opportunism. Other proponents of agency theory such as Kolk (2008), lenciu et al. (2012), and Buniamin et al. (2011) argue that effective governance can reduce the agency problems by holding managers accountable to the wide variety of stakeholders.

Agency and stakeholder theories complement each other by advocating the alignment of shareholders, stakeholders and management goals. Both frameworks discourage the opportunistic behaviour of management (Michelon and Parbonetti 2012). This fact provides the rationale of combining both theories to explain corporate governance and performance link.

\section{Methodology of research}

\subsection{Research Design}

The research design adopted for this study was ex-post facto research design. Ex post facto research is a systematic empirical inquiry in which the researcher does not have direct control of independent variables and in which groups of participants are determined by pre-existing conditions and events from the past.

\subsection{Population of the Study}

The population of this study is made up of all seven six manufacturing companies listed on the Nigerian Stock Exchange as at 2016. The companies are classified under 6 sectors which include agriculture; conglomerates; consumer goods; healthcare; information \& communications technology and industrial goods sectors. The study covered thirteen years annual reports and accounts of these companies from 2004 to 2016.

\subsection{Sampling and Sampling Technique}

Complete enumeration of the population was adopted as sample for this study. However, the purposive sampling technique was used to select the thirty two (32) listed manufacturing companies on the Nigerian stock exchange, with complete and detailed information during the period that was used for the study.

\subsection{Method of Data Collection and Analysis}

The data for this research were collected from secondary sources. The data were sourced from publications of the Nigerian stock exchange (NSE), fact books and the annual report and accounts of the 
selected quoted companies. Multiple regressions were utilized with the aid of E-view 9.0 statistical software to analyse data. This was used to ascertain whether there is a significant relationship between the dependent and independent variables.

\subsection{Model Specification}

The model formulated for this study is given as thus:

$B H=f\left(\beta O+\beta_{1} C_{\text {CGSIZE }}-1+\beta_{2} C_{\text {CGWB }}+\beta_{3}\right.$ CGBID $)$

Where:

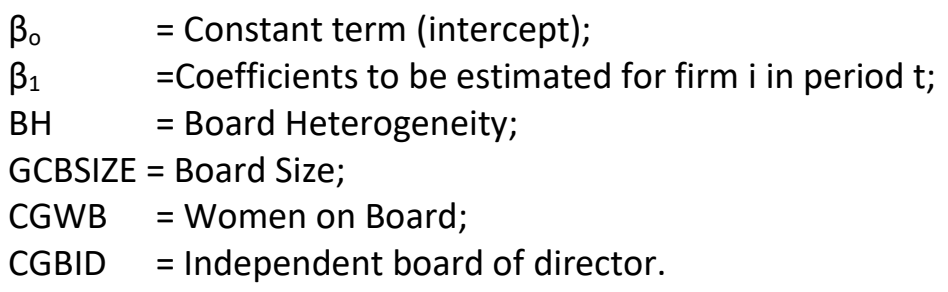

Stating the model in an explicit stochastic form gives:

$R O A=\beta_{0}+\beta_{1} C_{\text {CGBSIZE }}-1+\beta_{2} C_{\text {CGWB }-1}+\beta_{3}$ CGBIDt $_{-1}+e_{t}$

All variables are as previously defined. $\beta_{0}$ is the coefficient (constant), $\beta_{1}-\beta_{3}$ are parameters of the independent variables to be estimated, $e$ is standard error, $t$ is current period while $t-i$ (where $i=1$ ) stands for one year lag period. Decision Rule: Reject the null hypothesis for the alternative if the F-value is less than $5 \%$ otherwise accepts it.

\subsection{Variable Description}

\begin{tabular}{|c|l|c|l|}
\hline S/N & \multicolumn{1}{|c|}{ Variables: } & Code & Measurement \\
\hline $\mathbf{1}$ & Dependent variables & \multicolumn{3}{|l|}{} \\
\hline A & Return on asset & (ROA) & $\checkmark$ \\
\hline $\mathbf{2}$ & Independent variables & Net income/Total Assets \\
\hline A & Board Size & (BSIZE) & Total number of Board of Directors \\
\hline B & Women on Board & (CGWB) & Total number of women on the Board \\
\hline C & Board Independence & (CGBID) & Percentage of external directors on the Board \\
\hline $\mathbf{3}$ & Control variable & (FSIZE) & Log of total assets \\
\hline A & Firm size &
\end{tabular}

Source: Researchers' Computation 2018

\section{Data analysis}

Table 1. Descriptive Statistics of Operational Variables

\begin{tabular}{lccccc}
\hline & CGBID & CGBSIZE & CGWB & ROA & FSIZE \\
\hline Mean & 5.865889 & 10.48572 & 1.538462 & 5.444567 & 8.640769 \\
Median & 5.720000 & 12.00000 & 1.000000 & 5.370000 & 8.860000 \\
Maximum & 8.910000 & 13.45000 & 3.000000 & 6.530000 & 9.970000 \\
Minimum & 3.410000 & 5.070000 & 1.000000 & 0.300000 & 7.390000 \\
Std. Dev. & 1.527102 & 2.464881 & 0.635088 & 0.594797 & 0.469201 \\
Skewness & 0.355707 & -0.794802 & 0.759707 & -3.123781 & -0.279329 \\
Kurtosis & 2.276925 & 2.248189 & 2.555363 & 27.61722 & 2.547505 \\
Jarque-Bera & 17.83508 & 53.59572 & 43.44291 & 11180.69 & 8.958738 \\
Probability & 0.000134 & 0.000000 & 0.000000 & 0.000000 & 0.011341 \\
Sum & 2440.210 & 4362.060 & 640.0000 & 2264.940 & 3594.560 \\
Sum Sq. Dev. & 967.7963 & 2521.389 & 167.3846 & 146.8199 & 91.36215 \\
Observations & 416 & 416 & 416 & 416 & 416 \\
\hline
\end{tabular}

Source: Researcher's Computation Using E-View 9.0 


\section{Interpretation}

From the table above, the mean is a tool for setting benchmark. The median helps in re-ranking and taking the central tendency. Also, the minimum and maximum values help in detecting problem in a data. The standard deviation reveals the deviation from the mean. It measures risk; the higher the standard deviation the higher the risk. The skewness and Kurtosis are contained in Jarque_Bera. Jarque_bera is used to test for normality; to know whether data are normally distributed. Jarque_Beratheory posits that, if probability value is less than $10 \%$ we accept the alternative $\left(H_{1}\right)$ meaning that the data are normally distributed if not accept the null, meaning that they are not normally distributed.

\subsection{Test of Hypothesis}

H0: Board size, Women on Board and Board independence does not significantly affect return on asset (ROA)

Table 2. Multiple regressions showing the effect of CGBSIZE, CGWB, CGBID on ROA

\begin{tabular}{|c|c|c|c|c|}
\hline $\begin{array}{l}\text { Dependent Variable: } \\
\text { Method: Panel Least } \\
\text { Date: 04/16/18 Tim } \\
\text { Sample: } 20042016 \\
\text { Periods included: } 13 \\
\text { Cross-sections includ } \\
\text { Total panel (balance }\end{array}$ & $\begin{array}{l}\text { ares } \\
1: 31 \\
32 \\
\text { servations: } 4\end{array}$ & & & \\
\hline Variable & Coefficient & Std. Error & t-Statistic & Prob. \\
\hline C & 0.169371 & 0.149934 & 34.47759 & 0.0000 \\
\hline CGBSIZE & 0.004527 & 0.015048 & 2.294532 & 0.0223 \\
\hline CGWB & -0.010604 & 0.046077 & -0.230128 & 0.8181 \\
\hline CGBID & -0.012024 & 0.024227 & -0.496309 & 0.6199 \\
\hline R-squared & 0.725866 & Mean depe & lent var & 5.444567 \\
\hline Adjusted R-squared & 0.658700 & S.D. depen & ht var & 0.594797 \\
\hline S.E. of regression & 0.592204 & Akaike info & iterion & 1.799636 \\
\hline Sum squared resid & 144.4905 & Schwarz cr & rion & 1.838393 \\
\hline Log likelihood & -370.3243 & Hannan-Qu & n criter. & 1.814960 \\
\hline F-statistic & 2.214075 & Durbin-Wa & n stat & 0.943287 \\
\hline Prob(F-statistic) & 0.002906 & & & \\
\hline
\end{tabular}

Source: Researcher's Computation Using E-View 9.0, 2018

\section{Interpretation}

Regression coefficients represent the mean change in the response variable (ROA) for one unit of change in the predictor variable while holding other predictors in the model constant. The following regression equation was obtained in table 2 .

$$
\text { ROA }=-0.169371+0.004527 \text { CGBSIZE }
$$

Using the above model, it is possible to determine the relationship between CGBSIZE and ROA of listed manufacturing firms. Holding all other factors constant, an increase in one unit of the independent variable (CGBSIZE) results into a corresponding increase in one unit of ROA of listed manufacturing firms, this means that a positive relationship exists between CGBSIZE and ROA. The independent variable in the above model, however, is significant since the $p$-value of the independent variable is less than $5 \%$ as shown in table 2 above.

The slope coefficient show that that the probability value is $\mathrm{P}\left(\mathrm{x}_{1}=0.0223<0.05\right)$ is less than the critical $P$-value of 0.05 . This implies that CGBSIZE has a positive significant relationship with ROA.

Results in table 2 also indicate that the adjusted R-squared for the model is 0.65 , meaning that the regression model used for this study is a good predictor. The independent variables explained $65 \%$ of the 
variation in ROA of listed manufacturing firms. Only $35 \%$ of variation in ROA of listed manufacturing firms is not explained by the regression model.

The Durbin-Watson value of 0.943287 indicates the absence of serial correlation in the model.

From the test of coefficients result, the probability value of the F-statistics $=0.002906$ implies that the regression model is significant in predicting the relationship between the independent variable (CGBSIZE) and the dependent variable (ROA). The significance between the variables is less than $\alpha=0.05$. This result indicates that the overall regression model is statistically significant and is useful for prediction purposes at $5 \%$ significance level.

\section{Decision Rule:}

Accept $\mathrm{H}_{1}$ if the P-Value of the test is less than $\alpha$-value (level of significance) at $5 \%$.

\section{Decision:}

The P-Value of the test Prob(F-statistic) $=0.002906$ is less than the $\alpha$-value value of 0.05 ; therefore $\mathrm{H}_{1}$ is accepted and $\mathrm{Ho}$ is rejected.

\subsection{Discussion of findings}

The thrust of this study is to ascertain the effect of corporate board heterogeneity on the performance of manufacturing firms in Nigeria. Specifically, the study finds a significant positive relationship between Board size; Women on Board and Board independence. This is in line with the study of Bello and Kamarul (2017), in Nigeria, which examined 'Board Governance Mechanisms and Sustainability Disclosure: A Moderating role of Intellectual Capital' and revealed that board size, board independence and board diversity were found to enhance the disclosure of sustainability information. Their results also revealed that intellectual capital has a significant positive effect on the relationship between board size, board independence, board diversity and sustainability disclosure.

The findings of this study revealed that corporate board heterogeneity (BSIZE, CGWB and CGBID) has a positive and statistically significant relationship with ROA of listed manufacturing firms on NSE at $5 \%$ significant level.

\section{Conclusions and recommendations}

\subsection{Conclusions}

Effective board heterogeneity practice leads to maximization of shareholders wealth legally, ethically and on a sustainable basis while ensuring equity and transparency to all stakeholders.

Board is the "heart" of corporate governance where the outcome of a firm is often determined. Therefore, effective board heterogeneity ensures maximum protection of stakeholders' interest, efficient monitoring and management of risk, as well as the provision of the effective control mechanism imperative to optimization of corporate performance.

\subsection{Recommendations}

In line with the findings of this study, the following recommendations were made:

1. Board size should be in line with corporate size and activities as setting arbitrary benchmark for board size may not be productive especially in relatively small firms.

2. Firms should endeavor to diversify their board for improved groupthink and board effectiveness.

3. Firms should ensure that majority of their board members are independent meaning that the directors are not employees of the company and do not depend on it for their livelihood so that they can fearlessly and honestly monitor the activities of the CEO and other directors (executives). This will help constraint CEO and executive directors from taking advantage or exploiting other stakeholders. 


\section{References}

1. Abdulazeez DA, Ndibe L., \& Mercy AM. (2016). Corporate governance and financial performance of listed deposit money banks in Nigeria. J Account Mark 5, 153-159. doi:10.4172/2168-9601.1000153.

2. Abdullah, S. N., Mohamad, N. R., \& Mokhtar, M. Z. (2011). Board independence, ownership and CSR of Malaysian large firms. Corporate Ownership and Control, 8(3), 417-431.

3. Adams, R. B., \& Ferreira, D. (2009). Women in the boardroom and their impact on governance and performance. Journal of Financial Economics, 94(2), 291-309. http://doi.org/10.1016/j.jfineco.2008.10.007.

4. Adjaoud, F., Zeghal, D., \& Andaleeb, S. (2007). The effect of board's quality on performance: A study of Canadian firms. Corporate Governance: An International Review, 15(4), 623-635. http://dx.doi.org/10.1111/j.1467-8683.2007.00592.x

5. Aguilera R.V., Filatotchev, L., Gospel, H. \& Jackson, G. (2007). An organizational approach to comparative corporate governance: Costs contingencies and complimentaries. Organization Science, 19:475-492.

6. Akhtaruddin, M., Hossain, M. A., Hossain, M., \& Yao, L. (2009). Corporate governance and voluntary disclosure in corporate annual reports of Malaysian listed firms. Jamar, 7(1),1-20.

7. Al-Moataz, E., \& Hussainey, K. (2012). Determinants of corporate governance disclosure in Saudi companies. Journal of Economics and Management, 5(1), 52-84.

8. Al-Shammari, B., \& Al-Sultan, W. (2010). Corporate governance and voluntary disclosure in Kuwait. International Journal of Disclosure and Governance, 7(3), 262-280.

9. Bear, S., Rahman, N. \& Post, C. (2010). The impact of board diversity and gender composition on corporate social responsibility and firm reputation. Journal of Business Ethics, 97(2), 207-221. http://doi.org/10.1007/s10551-010-0505-2.

10.Brajesh, K. (2010). Competing human interest: The key domain for effective corporate governance. Advances in Management, 3(11), 210-225.

11.Carter, D. A., Simkins, B. J., \& Simpson, W. G. (2003). Corporate Governance, Board Diversity, and Firm Value. The Financial Review, 38(1), 33-53. http://doi.org/10.1111/1540-6288.00034.

12.Clarke, T. (2007). Theories of Corporate Governance: The Philosophical Foundations of Corporate Governance. Routledge, Taylor \& Francis Group, London, New York.

13.Dar, L.A., Naseem, M.A., Rehman, R.U. \& Niazi, G.S. (2011). Corporate governance and firm performance: A case study of Pakistan oil and gas companies listed in Karachi stock exchange. Global Journal of Management and Business Research, 11(8), 1-9. Retrieved from: www.journalofbusiness.org/ index.../469.

14.Dombin, A.N. (2013). Role of corporate governance in attracting investments in Nigeria. Journal of Educational \& Social Research,3(9), 35-42.

15.Donaldson, L., \& Muth, M.M. (1998). Stewardship theory and board structure: A contingency approach. Corporate Governance- An International Review, 6(1), 5-28.

16.Donaldson, W.H. (2003). Corporate governance. Business Economics, 38, 16-20.

17.Dutta, P. \& Bose, S. (2006), Gender diversity in the boardroom and financial performance of commercial banks: Evidence from Bangladesh. The Cost and Management, 34(6), 70-74.

18.Esa, E., \& Mohd-Ghazali, N. A. (2012). Corporate social responsibility and corporate governance in Malaysian government-linked companies. International Journal of Business in Society, 12(3), 292-305. http://doi.org/10.1111/j.1468-0270.2009.01940.x.

19.Fernandez-Feijoo, B., Romero, S., \& Ruiz, S. (2012). Does board gender composition affect corporate social responsibility reporting? International Journal of Business and Social Science, 3(1), 31-38.

20.Fernando, A.C. (2006). Corporate governance: Principles, policies and practices. New Delhi: Dorling Kindersley.

21.Filatotchev, I. \& Boyd Bk. (2009). Taking stock of corporate governance research while looking to the future. Corporate Governance: An International Review, 17(3), 257-265.

22.Fodio, M. I., \& Oba, V. C. (2012). Boards' gender mix and extent of environmental responsibility information disclosure in Nigeria: An empirical study. European Journal of Business and Management, 4(14), 163-169.

23.Freeman, R.E. (1984). Strategic Management: A Stakeholder Approach. London: Pitman. 
24.Gul, F. A., \& Leung, S. (2004). Board leadership, outside directors' expertise and voluntary corporate disclosures. Journal of Accounting and Public Policy, 23(5), 351-379. doi:10.1016/j.jaccpubpol. 2004.07.001.

25. Hagel, J., Brown, J. and Davison, L. (2010). The Best Way to Measure Company Performance. [online] Harvard Business Review. Available at: https://hbr.org/2010/03/the-best way-to-measurecompan.html.

26.Haji, A. A., \& Mohd-Ghazali, N. A. (2013). A longitudinal examination of intellectual capital disclosures and corporate governance attributes in Malaysia. Asian Review of Accounting, 21(1), $27-52$.

27.Halme, M., \& Huse, M. (1997). The influence of corporate governance, industry and country factors on environmental reporting. Scandinavian Journal of Management, 13(2), 137-157. doi:10.1016/ S0956-5221(97)00002-X.

28. Hambrick D.C., Werder, A. \& Zajac E.J. (2008). New directions in corporate governance research. Organization Science, 19(3), 381-385.

29. Haniffa, R. M., \& Cooke, T. E. (2005). The impact of culture and governance on corporate social reporting. Journal of Accounting and Public Policy, 24(5), 391-430. http://doi.org/10.1016/j.jaccpubpol. 2005.06.001

30.Harjoto, M., Laksmana, I., \& Lee, R. (2014). Board diversity and corporate social responsibility. Journal of Business Ethics, 132(4), 641-660. http://doi.org/10.1007/s10551-014-2343-0

31. Harrison, J. S., \& Coombs, J. E. (2012). The moderating effects from corporate governance characteristics on the relationship between available slack and community-based firm performance. Journal of Business Ethics, 107(4), 409-422. http://doi.org/10.1007/s10551-011-1046-z.

32.Ho, P. L., \& Taylor, G. (2013). Corporate governance and different types of voluntary disclosure. Pacific Accounting Review, 25(1), 4-29.

33. Hough, J., Thompson, A.A., Strickland, A.J. \& Gamble, J.E. (2011). Crafting and executing strategy: Creating sustainable high performance in South Africa: Text, readings and cases. Second edition. London: McGraw-Hill.

34.Huang, C. (2010). Corporate governance, corporate social responsibility and corporate performance. Journal of Management and Organization, 16(5), 641-655. http://doi.org/10.1017/S1833367 200001784.

35.Huse, M. \& Solberg, A. (2006). Gender-related boardroom dynamics: How Scandinavian women make and can make contributions on corporate boards. Women in Management Review, 21(2), 113-130.

36. Hussain, N., Rigoni, U., \& Orij, R. P. (2016). Corporate governance and sustainability performance: Analysis of triple bottom line performance. Journal of Business Ethics, Springer, doi 10.1007/s10551-0163099-5.

37.Ibrahim, N. A., \& Angelidis, J. P. (2011). Effect of board members' gender on corporate social responsiveness orientation. Journal of Applied Business Research, 10(1), 35-40.

38.Ireland, R.D., Hoskisson, R.E. \& Hitt, M.A. (2009). The management of strategy concepts. Ohio: South-Western Cengage Learning.

39.Janggu, T., Darus, F., Zain, M. M., \& Sawani, Y. (2014). Does good corporate governance lead to better sustainability reporting? An analysis using structural equation modeling. Procedia-Social and Behavioral Sciences, 145, 138-145. http://doi.org/10.1016/j.sbspro.2014.06.020.

40.Jensen, M. (1993). The modern industrial revolution, exit and the failure of internal control systems. Journal of Finance, 48,831-880. http://dx.doi. org/ 10.2307/2329018

41.Jensen, M. C., \& Meckling, W. H. (1976). Theory of the firm: Managerial behavior, agency costs and ownership structure. Journal of Financial Economics, 3(4), 305-360.

42.Jo, H., \& Harjoto, M. (2011). Corporate governance and firm value: The impact of corporate social responsibility. Journal of Business Ethics, 103(3), 351-383. doi: 10.1007/s10551-011- 0869-y.

43.Jo, H., \& Harjoto, M. A. (2012). The causal effect of corporate governance on corporate social responsibility. Journal of Business Ethics, 106(1), 53-72. http://doi.org/10.1007/s10551-011-1052-1.

44.Johnson, R. A., \& Greening, D. W. (1999). The effects of corporate governance and institutional ownership types on corporate social performance. Academy of Management Journal, 42(5), 564-576. 
45.Kang, H., Cheng, M. \& Gray, S. (2007). Corporate governance and board composition: Diversity and independence of Australian boards. Corporate Governance: An International Review, 15(2), 194-207.

46.Karamaou, I. and Vafeas, N. 2005. The Association between corporate boards, audit committees and management earnings forecasts: An empirical analysis. Journal of Accounting Research, 43 (3), 453-486.

47.Kaur, S., Raman, V. A., \& Singhania, M. (2016). Impact of corporate characteristics on human resource disclosures. Asian Review of Accounting, 24(4), 390-425.

48.Khan, H. U. Z. (2010). The effect of corporate governance elements on corporate social responsibility (CSR) reporting. International Journal of Law and Management, 52(2), 82-109.

49.Kiel, G.C. \& Nicholson, G.J. (2003). Board composition and corporate performance: How the Australian experience informs contrasting theories of corporate governance. Corporate Governance, 11(3), 189-205.

50.Kim, K.A. \& Nofsinger, J.R. (2004). Corporate governance. New York: Pearson Prentice Hall.

51.Li, J., Pike, R., \& Haniffa, R. (2008). Intellectual capital disclosure and corporate governance structure in UK firms. Accounting and Business Research, 38(2), 137-159. doi: 10.1080/00014788. 2008.9663326.

52.Michelon, G., \& Parbonetti, A. (2012). Stakeholder engagement: corporate governance and sustainability disclosure. Journal of Management and Governance, 16(3), 477-509.

53.Murthy, N.R.N. (2006). Good corporate governance: A checklist or a mindset? Robert P. Maxon Lecture, George Washington University.

54.Nwagbara, U., \& Ugwuoji, C. A. (2014). Corporate governance, CSR reporting and accountability: The case of Nigeria. Economic Insights - Trends and Challenges, 4(1), 77-84.

55.Post, C., Rahman, N., \& Rubow, E. (2011). Green governance: Boards of directors' composition and environmental corporate social responsibility. Business \& Society, 50(1), 189-223. http://doi.org/ $10.1177 / 0007650310394642$.

56.Rao, K. K., Tilt, C. a., \& Lester, L. H. (2012). Corporate governance and environmental reporting: An Australian study. Corporate Governance, 12(2), 143-163. http://doi.org/10.1108/14720701211214052.

57.Rao, K., \& Tilt, C. (2015). Board composition and corporate social responsibility: The role of diversity, gender, strategy and decision making. Journal of Business Ethics, 138(2), 327-347. http://doi.org/10.1007/s10551.

58.Rupley, K., Brown, D. \& Marshall, R. (2012). Governance, media and the quality of environmental disclosure. Journal of Accounting and Public Policy, 31(6), 610-640.

59.Said, R., Zainuddin, Y. H., \& Haron, H. (2009). The relationship between corporate social responsibility disclosure and corporate governance characteristics in Malaysian public listed companies. Social Responsibility Journal, 5(2), 212-226. doi: 10.1108/ 17471110910964496.

60.Seal, W. (2006). Management accounting and corporate governance: An institutional interpretation of the agency problem. Management Accounting Research, 17(4), 389-408.

61.Şener, I., \& Karaye, A. B. (2014). Board Composition and Gender Diversity: Comparison of Turkish and Nigerian Listed Companies. Procedia-Social and Behavioral Sciences, 150, 1002-1011. http://doi.org/ 10.1016/j.sbspro.2014.09.112.

62.Setó-Pamies, D. (2013). The relationship between women directors and corporate social responsibility. Corporate Social Responsibility and Environmental Management, 22(6), 334-345. http://doi.org/10.1002/csr.1349.

63.Sharif, M., \& Rashid, K. (2014). Corporate governance and corporate social responsibility (CSR) reporting: An empirical evidence from commercial banks (CB) of Pakistan. Quality \& Quantity, 48(5), 25012521. http://doi.org/10.1007/s11135-013-9903-8.

64.Shipilov, A.V., Greve, H.R. \& Rowley T. (2010). When do interlocks matter? Institutional logics and the diffusion of multiple governance practices. The Academy of Management Journal, 53(4), 846-864.

65.Simons, R. (2000). Performance Measurement and Control System for Implementing Strategy: Text and Cases; Prentice Hall: Old Tappan, NJ, USA.

66.Visser, W. (2013). The age of responsibility: CSR 2.0 and the New DNA of Business London: Wiley.

67.Vo, H. D., \& Phan, B. T. (2013). The relationship between Corporate Governance and Firm Performance. Unpublished Paper, Ho Chi Minh City Open University. 
68.Wang, J., \& Coffey, B. (1992). Board composition and corporate philanthropy. Journal of Business Ethics, 11(10), 771-778. doi: 10.1007/BF00872309.

69.Wang, L., \& Lin, L. (2007). A methodology framework for the triple bottom line accounting and management of industry enterprises. International Journal of Production Research, 45(5), 1063-1088.

70.Webb, E. (2004). An examination of socially responsible firms' board structure. Journal of Management and Governance, 8(3), 255-277.

71.World Bank (2006). Report on the observance of standards and codes: Corporate governance. Retrieved from:www.worldbank.org/ifa/rosc.html.

72.Yermack, D. (1996). Higher market valuation of companies with a small board of directors. Journal of Financial Economics, 40, 185-211. http://dx.doi.org/10.1016/0304-405X(95)00844-5.

73.Zhang, J. Q., Zhu, H., \& Ding, H. (2013). Board Composition and Corporate Social Responsibility: An Empirical Investigation in the Post Sarbanes-Oxley Era. Journal of Business Ethics, 114(3), 381-392. http://doi.org/10.1007/s10551-012-1352-0. 